\title{
Experimental study on the effects of cement contamination in a water based mud
}

\author{
Eric Broni-Bediako ${ }^{\circledR} *$, Richard Amorin \\ Petroleum Engineering Department, University of Mines and Technology, Tarkwa, Ghana
}

(Received June 5, 2019; revised August 20, 2019; accepted August 21, 2019; available online August 28, 2019)

\section{Citation:}

Broni-Bediako, E., Amorin, R.

Experimental study on the effects of cement contamination in a water based mud. Advances in Geo-Energy Research, 2019, 3(3): 314-319, doi:

10.26804/ager.2019.03.09.

Corresponding author:

*E-mail: ebroni-bediako@umat.edu.gh

Keywords:

Cement

contaminant

fluid loss

gel strength

rheology

plastic viscosity

yeild point

\begin{abstract}
:
Drilling mud is used to ensure save and cost-effective drilling operations. In every phase of the drilling operation, contaminants are encountered which directly affect the properties of the drilling mud. The severity of drilling mud contamination depends on the type of drilling mud used, the type of contaminant and the degree of contamination. In most drilling operations, cement contamination occurs one or more times when casing strings are cemented and the plugs are drilled out. Drilling mud is discarded when cement contamination is too high such that it is practically unreasonable to treat it. It is therefore important to monitor the mud's properties against contamination to ensure the basic functions of the mud. To perform effective monitoring of a drilling mud requires proper knowledge of the drilling mud chemistry, properties, and contaminants. This will help oil operators to apply the right control measures and treatment methods during drilling operations. This paper presents an experimental study on the effect of various concentrations of cement contamination on some physical properties of water based mud (WBM). Four mud samples were prepared of which three of them were contaminated with $10 \mathrm{~g}, 20 \mathrm{~g}$ and $30 \mathrm{~g}$ of class $\mathrm{G}$ cement. Rheological properties at temperatures of $25^{\circ} \mathrm{C}$, $40{ }^{\circ} \mathrm{C}$ and $60{ }^{\circ} \mathrm{C}$ as well as the $\mathrm{pH}$, fluid loss and density of the mud were determined. The findings showed that the yield point and gel strength at all test temperatures increased as the concentration level of cement increased. However, the plastic viscosity decreased slightly with cement concentration of $10 \mathrm{~g}$ and $20 \mathrm{~g}$ and further increased with $30 \mathrm{~g}$ of cement contamination at $40{ }^{\circ} \mathrm{C}$ and $60{ }^{\circ} \mathrm{C}$. The fluid loss, density as well as the pH of the WBM increased gradually as the concentration of cement increased. It is recommended that the effect of cement contamination in WBM at temperatures higher than $60{ }^{\circ} \mathrm{C}$ should be investigated.
\end{abstract}

\section{Introduction}

Petroleum is one of the world's most important natural resources impacting positively on many nations. As a result of continuous demand for energy by the world, more exploration and drilling activities are carried out to produce oil and gas in commercial quantities. Drilling operations are capital intensive and this calls for the use of properly designed drilling fluid to avoid wellbore instability issues. Drilling fluid used for drilling operations could be liquid base (water base and oil base mud), gaseous base (air and natural gas) or gas-liquid mixture base (foam and aerated water). The type of formation to be drilled influences the selection of drilling fluid system to be used. During drilling operations, the mud flows continuously into and out of the wellbore as it performs major functions such as carrying out drilled cuttings from the wellbore to surface, cooling and lubricating the drill bit, removing rock debris and drill cuttings from the site and providing sufficient hydrostatic pressure against the formation penetrated and many others (Nasser et al., 2013; Henaut et al., 2015). The rapid expanding needs of drilling mud as a result of severe high temperature and high pressure, increase in technical demand and governmental regulations on mud disposal as well as environmental remediation have brought about evolution of several drilling fluid designs (Khodja et al., 2010).

Nevertheless, during drilling operations, these drilling fluids are contaminated with all kinds of solids and formation liquids. These contaminants include salts, gypsum/anhydrite, and cement among others. The severity of drilling mud contamination depends on the type of drilling mud used, the type of contaminant and the degree of contamination. In most drilling operations, cement contamination occurs one or more times when casing strings are cemented (drilling cement after each casing or liner is set) and the plugs are drilled out (Amoco, 1994). Contaminants alter the chemical and physical properties of the drilling mud which results in wellbore instability issues. Drilling mud is discarded when 
cement contamination is too high such that it is practically unreasonable to treat it. This increases the cost of drilling. It is therefore important to monitor the properties of drilling mud against contamination to ensure the basic functions of the mud system. To perform effective monitoring of a drilling mud requires proper knowledge of the drilling mud chemistry, properties, and contaminants. This will help oil operators to apply the right control measures and treatment methods during drilling operations. This paper presents an experimental study on the effects of cement contamination on some physical properties of water based mud (WBM).

\section{Drilling mud contaminants}

Drilling mud contaminants are any material that causes undesirable alterations of the drilling mud properties such as density, viscosity, gel strength and filtration when it is incorporated in the mud system. These contaminants enter the mud system to adversely affect its quality and reduce its overall performance. Drilling mud contaminants can come from the formation, thermal degradation of organics in mud, or aeration or overtreatment at the surface. The main contaminants are (Mitchell and Lake, 2006):

i. Calcium-Ions: Calcium ions are present in makeup water (particularly sea water), formation water and mixed salt evaporite formations. They are also encountered in greatest quantity when drilling cement or anhydrite. The presence calcium ion in mud tends to replace the sodium ions on the clay surface through a base exchange, thus causing undesirable changes in mud properties such as rheology and filtration.

ii. Salt/Saltwater Flows: The ions, $\mathrm{Na}^{+}$and $\mathrm{Cl}^{-}$may enter the drilling mud system from drilling salt sections or formation saltwater. It causes the mud system to have high yield strength, high fluid loss and $\mathrm{pH}$ decrease.

iii. Bicarbonate and Carbonate Contamination: The sources of contaminant ions $\left(\mathrm{CO}_{3}^{2-}, \mathrm{HCO}_{3}^{-}\right)$are from drilling a $\mathrm{CO}_{2}$-bearing formation and thermal degradation of organics in mud. Overtreatment of mud system contaminated by other sources with soda ash or sodium bicarbonate can also contribute to the problem known as "carbonate alkalinity".

iv. Hydrogen Sulphide $\left(\mathrm{H}_{2} \mathrm{~S}\right)$ : The contaminant ions $\left(\mathrm{HS}^{-}\right.$, $\mathrm{S}^{2-}$ ) may enter the mud system from drilling an $\mathrm{H}_{2} \mathrm{~S}$-bearing formation. Hydrogen sulphide is the deadliest ions to humans and is extremely corrosive to steel used during drilling operations. Its entrance into drilling mud will causes hydrogen embrittlement of steel pipes.

\section{Materials and methods}

\subsection{Materials}

The materials used for the experiment are class $\mathrm{G}$ cement, bentonite, mix-water, barite, soda ash, carboxyl methyl cellulose (CMC) and calcium chloride.

\subsection{Mud preparation}

Mud sample (Set 1) was prepared by measuring $350 \mathrm{ml}$ of mix-water into a chandler engineering mixer cup. 22.5 $\mathrm{g}$ of bentonite was added and prehydrated for 30 minutes under stirring condition to obtain a homogeneous mixture. The sample was transferred into a sealed jar and aged for 16 hours. $2.5 \mathrm{~g}$ of $\mathrm{CMC}$ was later added to the aged bentonite and stirred for 5 minutes using the electronic hand mixer followed by $5 \mathrm{~g}$ of calcium chloride for another 10 minutes. Then a $5 \mathrm{~g}$ of barite was added and the mixture was stirred further for another 5 minutes to homogenise before the rheological and physical properties were measured. Three other samples: Set 2, Set 3 and Set 4 were prepared by repeating the mixing procedure just as that of sample Set 1 but, different masses of $10 \mathrm{~g}, 20 \mathrm{~g}$ and $30 \mathrm{~g}$ of cement were added to the formulated muds respectively. Thereafter, the rheological and some physical properties were determined.

\subsection{Rheology test}

Rheology is study of the deformation and flow characteristics of a matter. Rheology of drilling fluid provide relevant information required in the design of circulating systems. The importance of rheology is seen in the analysis of fluid flow velocity profiles, fluid viscosity, friction pressure losses and annular wellbore cleaning. Rheological properties are foundation for all analysis of drilling hydraulics and to assess how a mud system functions (Darley and Gray, 1988; Dhiman, 2012; Nasser et al., 2013; Awele, 2014). The rheology of all the drilling fluid samples were measured using Fann viscometer. The results from the viscometer were used to compute the plastic viscosity (PV) and yield point (YP) of the samples using Eqs. (1) and (2) respectively (Ogbeide and Igbinere, 2016; Yunita et al., 2016).

$$
\begin{gathered}
P V: c P=\theta_{600}-\theta_{300} \\
Y P: \frac{1 b}{100} f t^{2}=\theta_{300}-P V
\end{gathered}
$$

\subsection{Fluid loss test}

Fluid loss is the measurement of filtrate passing from a drilling mud into a porous permeable formation. A good drilling mud should form a thin filter cake on the sides of the wellbore to prevent excessive fluids loss into the formation. Low fluid loss is a characteristic of good drilling fluids and vital to the integrity of the wellbore. Some factors that affect the fluid loss properties include time, temperature, cake compressibility; but also, the nature, amount and size of solids present in the drilling fluid (Khodja et al., 2010; Nasser et al., 2013). The fluid loss of all the drilling fluids were tested using a filter press.

\section{Results and discussion}

\subsection{Density}

Fig. 1 shows the results of density test performed on all the mud samples using a mud balance. From Fig. 1, the density of mud sample increased slightly as the amount of class $G$ 


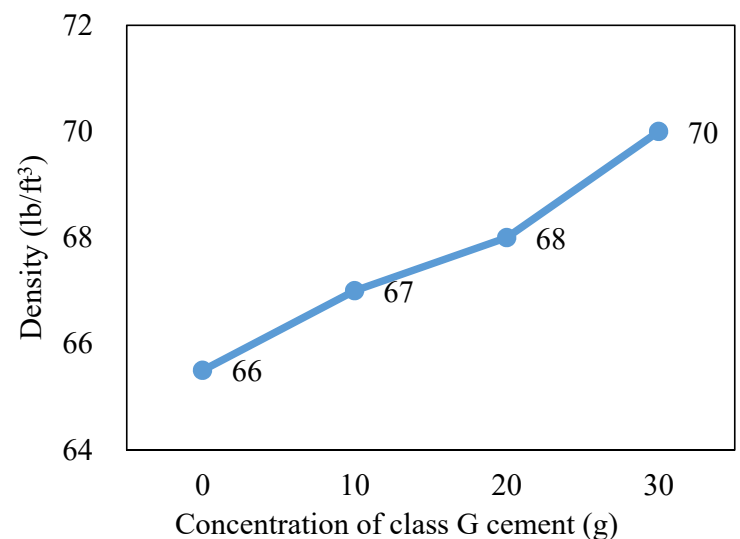

Fig. 1. Density of WBM with different cement concentrations at $25{ }^{\circ} \mathrm{C}$.

cement (contaminant) added to the WBM increased. The density of Set 1 sample was $65.5 \mathrm{lb} / \mathrm{ft}^{3}$ and this increased to $67 \mathrm{lb} / \mathrm{ft}^{3}$ (Set 2), $68 \mathrm{lb} / \mathrm{ft}^{3}$ (Set 3) and $70 \mathrm{lb} / \mathrm{ft}^{3}$ (Set 4) when contaminated with $10 \mathrm{~g}, 20 \mathrm{~g}$ and $30 \mathrm{~g}$ of class $\mathrm{G}$ cement respectively. This increase in density is due to the extra amount of fine solid particles contributed by the cement in the WBM. In addition, the increase in density may be due to the gradual hydration of the cement particles as calcium silicate hydrate (Bahand and Sulem, 2017).

\subsection{Mud pH}

Drilling fluid $\mathrm{pH}$ is the most important factor in tubular corrosion control. It also influences the equilibrium of reactions that impact the chemical structure and properties of drilling fluids (Mohamadian et al., 2018). Table 1 shows the $\mathrm{pH}$ of the mud system contaminated with different cement concentrations at $25{ }^{\circ} \mathrm{C}$.
Table 1. $\mathrm{pH}$ of WBM with different cement concentrations at $25^{\circ} \mathrm{C}$.

\begin{tabular}{llll}
\hline $0 \mathrm{~g}$ & $10 \mathrm{~g}$ & $20 \mathrm{~g}$ & $30 \mathrm{~g}$ \\
\hline 8.14 & 10.38 & 10.48 & 10.58 \\
\hline
\end{tabular}

From Table 1, the $\mathrm{pH}$ of the WBM increased gradually as the concentration level of contaminant (class $\mathrm{G}$ cement) increased. The $\mathrm{pH}$ of uncontaminated WBM (Set 1) was 8.14 and this increased to 10.38 (Set 2), 10.48 (Set 3) and 10.58 (Set 4) when contaminated with $10 \mathrm{~g}, 20 \mathrm{~g}$ and $30 \mathrm{~g}$ of class $\mathrm{G}$ cement respectively. The increase in $\mathrm{pH}$ is as a result of the increase in formation of calcium hydroxide resulting from the chemical reaction between the calcium component of the cement and the water portion of the mud. The calcium hydroxide tends to make the mud sample more basic.

\subsection{Rheological properties}

The experiment was performed at temperatures of $25^{\circ} \mathrm{C}$, $40{ }^{\circ} \mathrm{C}$ and $60{ }^{\circ} \mathrm{C}$ to determine the rheological properties of the contaminated WBM. The results are shown in Table 2.

\subsubsection{Rheological values}

Figs. 2, 3 and 4 show the rheological values of the contaminated WBM with different cement concentrations at different temperatures $\left(25^{\circ} \mathrm{C}, 40{ }^{\circ} \mathrm{C}\right.$ and $\left.60{ }^{\circ} \mathrm{C}\right)$. Comparing the rheological values at different concentration of cement, the rheological values at each temperature increased gradually as the concentration of the contaminant increased (Figs. 2, 3 and $4)$. The rheological values for $30 \mathrm{~g}$ cement concentration at $25{ }^{\circ} \mathrm{C}$ recorded $300+$ dial reading values after $6 \mathrm{rpm}$.

Table 2. Rheological properties of WBM with different cement concentrations and temperatures.

\begin{tabular}{|c|c|c|c|c|c|c|c|}
\hline \multirow{2}{*}{ Sample ID } & \multirow{2}{*}{ Temp. $\left({ }^{\circ} \mathrm{C}\right)$} & \multicolumn{6}{|c|}{ Dial readings $(\mathrm{cP})$} \\
\hline & & 3 & 6 & 100 & 200 & 300 & 600 \\
\hline \multirow{3}{*}{ Set 1} & 25 & 19 & 20 & 37 & 53 & 68 & 96 \\
\hline & 40 & 4 & 5 & 16 & 26 & 34 & 55 \\
\hline & 60 & 4 & 5 & 12 & 19 & 25 & 41 \\
\hline \multirow{3}{*}{ Set 2} & 25 & 22 & 30 & 90 & 107 & 116 & 150 \\
\hline & 40 & 16 & 21 & 65 & 74 & 80 & 92 \\
\hline & 60 & 13 & 16 & 51 & 57 & 64 & 75 \\
\hline \multirow{3}{*}{ Set 3} & 25 & 36 & 44 & 123 & 140 & 149 & 190 \\
\hline & 40 & 25 & 31 & 93 & 101 & 105 & 116 \\
\hline & 60 & 17 & 21 & 59 & 66 & 72 & 83 \\
\hline \multirow{3}{*}{ Set 4} & 25 & 101 & 120 & $300+$ & $300+$ & $300+$ & $300+$ \\
\hline & 40 & 59 & 65 & 181 & 216 & 228 & 264 \\
\hline & 60 & 24 & 30 & 79 & 89 & 93 & 112 \\
\hline
\end{tabular}




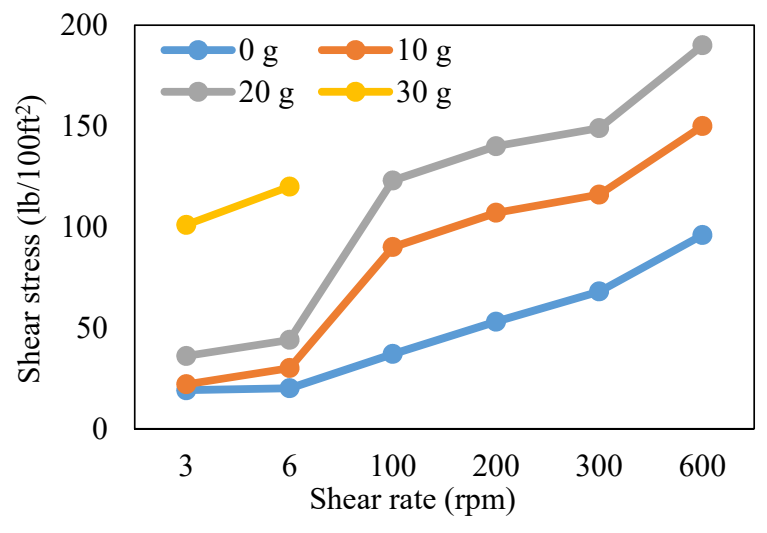

Fig. 2. Shear tress vs. shear rate at $25{ }^{\circ} \mathrm{C}$.

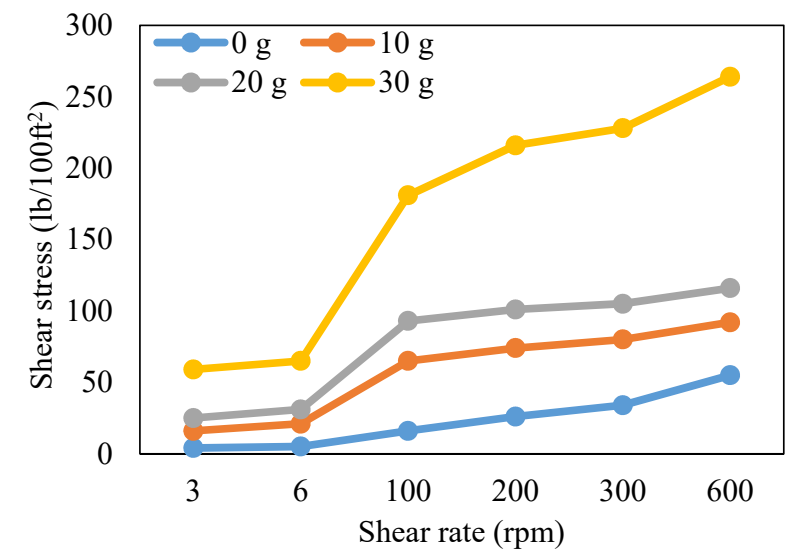

Fig. 3. Shear stress vs. shear rate at $40{ }^{\circ} \mathrm{C}$.

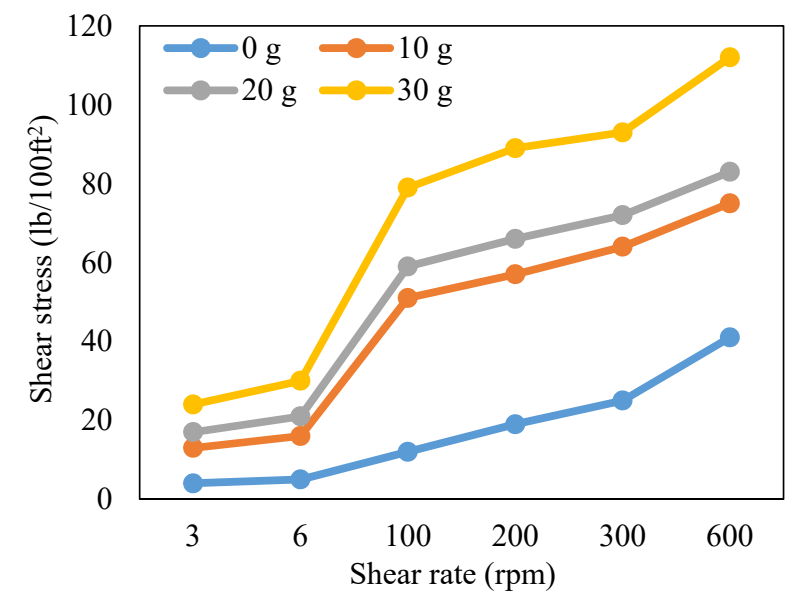

Fig. 4. Shear stress vs. shear rate at $60{ }^{\circ} \mathrm{C}$.

\subsubsection{Plastic viscosity}

Plastic Viscosity (PV) shows the fluids resistance to flow as a result of mechanical friction. This is attributed to the concentration, type, and size of solids present in a given fluid and the viscosity of the continuous phase. Should there be any increase in solid content such as barite, drill solids, loss circulation material and many others, this will then result in

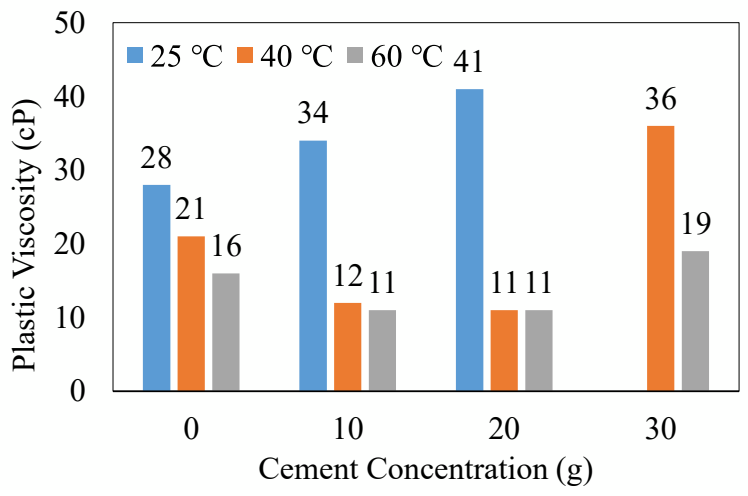

Fig. 5. Plastic viscosity of WBM with different cement concentrations at different temperatures.

higher plastic viscosity (Dankwa et al., 2018). The PV results for WBM contaminated with different cement concentrations at varying temperatures are represented in Fig. 5.

From Fig. 5, at $25{ }^{\circ} \mathrm{C}$, the plastic viscosity of WBM increased gradually as the concentration of contaminant increased. The PV of uncontaminated WBM (Set 1) was $28 \mathrm{cP}$. This increased to $34 \mathrm{cP}$ when contaminated with $10 \mathrm{~g}$ of class $\mathrm{G}$ cement (Set 2), and $41 \mathrm{cP}$ at $20 \mathrm{~g}$ of cement contamination (Set 3). For $30 \mathrm{~g}$ of cement contamination, the formulation gelled resulting in viscosity beyond the dial reading of the viscometer. Hence, PV of WBM cannot be calculated at 30 $\mathrm{g}$ of cement contamination. This increase in PV indicates an increase in solid particles (Joel et al., 2012).

As the temperature was increased to $40{ }^{\circ} \mathrm{C}$ and $60{ }^{\circ} \mathrm{C}$, plastic viscosity decreased steadily with $10 \mathrm{~g}$ and $20 \mathrm{~g}$ of class $\mathrm{G}$ cement contamination. A slight increase in plastic viscosity at $30 \mathrm{~g}$ of cement contamination was recorded. This decrease in PV according to Makinde et al. (2010) is as a result of increase in temperature of the base water used. As the temperature of the water increases, its viscosity decreases thereby reducing the PV of the mud. In addition, the calcium component of the cement tends to decrease the viscosity of the bentonite and this decreases the PV of the mud (Amorin, 2016). According to Nash (2013) also, the decrease in viscosity of the bentonite by calcium which reduces the $\mathrm{PV}$ of the mud is due to an increase in cation ionization. Cation ionization results in a decrease in the association of clay particles with a corresponding decrease in viscosity of bentonite until a certain threshold value is reached where cation ionization decreases and viscosity increases rapidly. This indicates that the repulsive potential barrier has been reduced to the kinetic energy of the clay particles.

\subsubsection{Yield point}

Table 3 presents the results of yield point (YP) of WBM with different cement concentrations at different temperatures. YP refers to the resistance to initial flow of the drilling mud. It is a measure of the electrical-chemical attractive forces in the drilling fluid under flowing conditions. YP depends on surface properties of mud solids, volume concentration of the solids, and concentration and type of ions within the fluid phase. If 
Table 3. Yield point of WBM with different cement concentrations at different temperatures.

\begin{tabular}{lllll}
\hline \multirow{2}{*}{ Temperature } & \multicolumn{4}{c}{ Weight of cement } \\
\cline { 2 - 5 } & $0 \mathrm{~g}$ & $10 \mathrm{~g}$ & $20 \mathrm{~g}$ & $30 \mathrm{~g}$ \\
\hline $25{ }^{\circ} \mathrm{C}$ & 40 & 82 & 108 & - \\
$40^{\circ} \mathrm{C}$ & 13 & 68 & 94 & 192 \\
$60{ }^{\circ} \mathrm{C}$ & 9 & 53 & 61 & 74 \\
\hline
\end{tabular}

YP appears to be high, it might mean there is strong attraction between the charged particles (Abdou et al., 2016; Yunita et al., 2016; Dankwa et al., 2018).

From Table 3, the YP of the WBM increased progressively as the concentration level of contaminant (class G cement) increased at $25{ }^{\circ} \mathrm{C}, 40{ }^{\circ} \mathrm{C}$ and $60{ }^{\circ} \mathrm{C}$. Considering the YP at $60^{\circ} \mathrm{C}$, uncontaminated WBM (Set 1 ) was $9 \mathrm{lb} / 100 \mathrm{ft}^{2}$ and this increased to $53 \mathrm{lb} / 100 \mathrm{ft}^{2}$ (Set 2), $61 \mathrm{lb} / 100 \mathrm{ft}^{2}$ (Set 3) and 74 $\mathrm{lb} / 100 \mathrm{ft}^{2}$ (Set 4) when contaminated with $10 \mathrm{~g}, 20 \mathrm{~g}$ and $30 \mathrm{~g}$ of class $\mathrm{G}$ cement respectively. The gradual increase in YP is due to the attractive force between the colloidal particles of the cement and that of the clay particles (bentonite). The bonding ability of the cement also increased the bonding ability of the overall fluid. According to Annis and Smith (2006), a sudden increase in $\mathrm{pH}$ is also the cause to the rise in yield point of the contaminated mud.

\subsubsection{Gel strength}

The results of gel strength at 10 seconds and 10 minutes of WBM with different cement concentrations at different temperatures are shown in Figs. 6 and 7 respectively. When the mud is static, the strength of any internal structure formed constitutes the gel strength of the mud. It indicates the pressure required to initiate flow after the mud had been static (Amorin, 2016). This feature of the drilling mud helps in suspending the drill cuttings along the length of the drillpipe/borehole annulus when the drilling mud circulation is stopped during tripping or any other secondary operation (Shah et al., 2010).

From Figs. 6 and 7, the gel strength at 10 seconds and 10 minutes respectively increased gradually as cement concentration and temperatures increased. This was due to the gelling/bonding tendency of the cement and the $\mathrm{pH}$ increase (Annis and Smith, 1996). Considering the gel strength at 10 seconds and 10 minutes at ambient temperature $\left(25^{\circ} \mathrm{C}\right)$, uncontaminated WBM (Set 1) was $19 \mathrm{lb} / 100 \mathrm{ft}^{2}$ at 10 seconds and $28 \mathrm{lb} / 100 \mathrm{ft}^{2}$ at 10 minutes. This increased further to 24 $\mathrm{lb} / 100 \mathrm{ft}^{2}$ at 10 seconds and $35 \mathrm{lb} / 100 \mathrm{ft}^{2}$ at 10 minutes for sample Set $2 ; 36 \mathrm{lb} / 100 \mathrm{ft}^{2}$ at 10 seconds and $46 \mathrm{lb} / 100 \mathrm{ft}^{2}$ at 10 minutes for sample Set 3 ; and $112 \mathrm{lb} / 100 \mathrm{ft}^{2}$ at 10 seconds and $172 \mathrm{lb} / 100 \mathrm{ft}^{2}$ at 10 minutes for sample Set 4 .

Similar trends were observed for gel strength at 10 seconds and minutes at $40{ }^{\circ} \mathrm{C}$ and $60{ }^{\circ} \mathrm{C}$ though increased in temperature effected the gel (breaking/weakening down the bonds). High static gel strength results in drilling problems such as bit balling, pipe sticking, and difficulty in running logging instruments downhole among others.

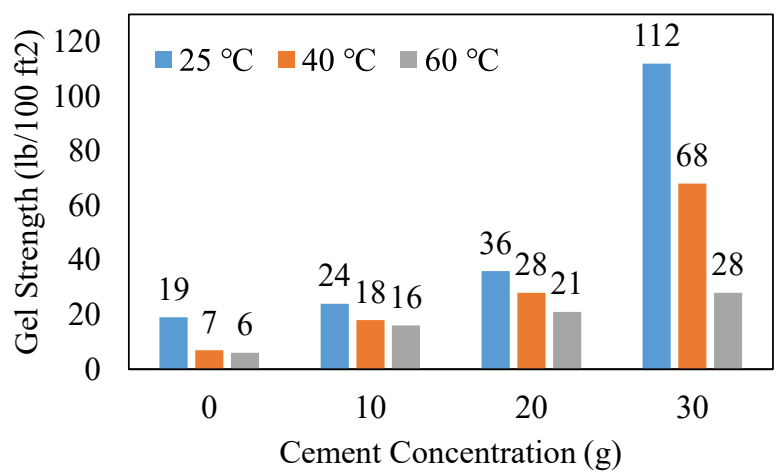

Fig. 6. 10 seconds gel strength of WBM with different cement concentrations at different temperatures.

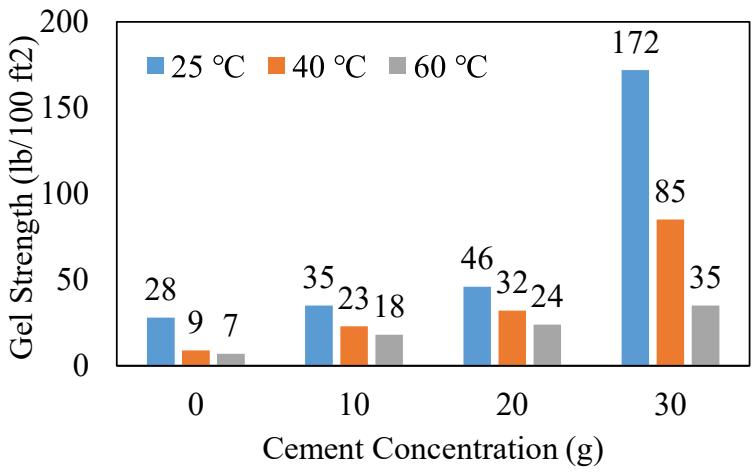

Fig. 7. 10 minutes gel strength of WBM with different cement concentrations at different temperatures.

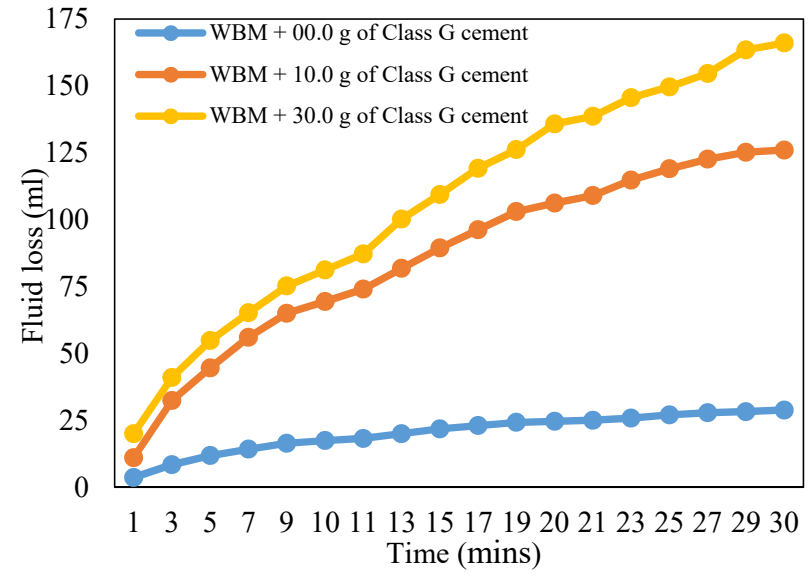

Fig. 8. Fluid loss of WBM with different cement concentrations at $25{ }^{\circ} \mathrm{C}$. 


\subsection{Fluid loss}

Fig. 8 shows the fluid loss test results with different cement concentrations at a temperature of $25^{\circ} \mathrm{C}$. It was observed that fluid loss increased with increased cement concentrations at $25{ }^{\circ} \mathrm{C}$. The increase in fluid may be due to flocculation of the fresh water bentonite systems by cement (Anon, 1994) caused by increase in $\mathrm{pH}$ of the mud system (Annis and Smith, 1996).

\section{Conclusions and recommendation}

This research investigated the effect of cement contamination on some physical properties of WBM. Varied concentrations of $10 \mathrm{~g}, 20 \mathrm{~g}$ and $30 \mathrm{~g}$ of powdered class $\mathrm{G}$ cement were added to the mud system. The following conclusions were drawn:

1) Mud density increased as the concentration of cement contamination increased and this shows the additional increase in solid content of the mud as well as the gradual hydration of the cement particles as calcium silicate hydrate.

2) Rheological values of the mud increased with increasing concentration of cement contamination at the various temperatures tested.

3) At $25^{\circ} \mathrm{C}$, plastic viscosity increased gradually as concentration of cement increased. However, the plastic viscosity at temperatures of $40{ }^{\circ} \mathrm{C}$ and $60{ }^{\circ} \mathrm{C}$ decreased gradually when the mud was contaminated with $10 \mathrm{~g}$ and $20 \mathrm{~g}$ of cement. It further increased slightly with $30 \mathrm{~g}$ of cement contamination.

4) Yield point and gel strength increased gradually as concentration of cement increased at the various temperatures tested.

5) Fluid loss increased with increased cement concentrations at $25{ }^{\circ} \mathrm{C}$ due to flocculation of the fresh water bentonite systems by cement.

6) The $\mathrm{pH}$ of the WBM increased gradually as the concentration level of cement increased.

It is recommended that the effect of cement contamination in WBM at temperatures higher than $60{ }^{\circ} \mathrm{C}$ should be investigated.

\section{Acknowledgments}

The authors would like to thank Mr Nuer Bright Teye Mensah and University of Mines and Technology, Tarkwa, Ghana for their support.

Open Access This article is distributed under the terms and conditions of the Creative Commons Attribution (CC BY-NC-ND) license, which permits unrestricted use, distribution, and reproduction in any medium, provided the original work is properly cited.

\section{References}

Abduo, M.I., Dahab, A.S., Abuseda, H., et al. Comparative study of using water-based mud containing multiwall carbon nanotubes versus oil-based mud in HPHT fields. Egypt. J. Petrol. 2016, 25: 459-464.

Amoco. Drilling fluid manual. Amoco Production Company, 1994.
Amorin, R. Drilling fluids. Unpublished BSc Lecture Notes, Tarkwa, University of Mines and Technology, 2016.

Annis, M.R., Smith, M.V. Drilling Fluid Technology. USA, Exxon Company, 1996.

Awele, N. Investigation of additives on drilling mud performance with Tonder geothermal drilling as a case study. Esbjerg, Aalborg University, 2014.

Bahand, S., Ghabezloo, S., Duc, M., et al. Effect of the hydration temperature on the microstructure of Class $G$ cement: C-S-H composition and density. Cem. Concr. Res. 2017, 95(3): 270-281.

Dankwa, O.K., Appau, O.P., Broni-Bediako, E. Evaluating the effects of monovalent and divalent salts on the rheological properties of water based mud. Open Petrol. Eng. J. 2018, 11(1): 98-106.

Darley, H.C.H., Gray, G.R. Composition and Properties of Drilling and Completion Fluids. Houston, USA, Gulf Professional Publisher, 1988.

Dhiman, A.S. Rheological properties and corrosion characteristics of drilling mud additives. Nova Scotia, Dalhousie University, 2012.

Henaut, I., Pasquier, D., Rovinetti, S., et al. HP-HT drilling mud based on environmently friendly fluorinated chemicals. Oil Gas Sci. Technol. 2015, 70(6): 917-930.

Joel, O.F., Ndubuisi, E.C., Ikeh, L. Effect of cement contamination on come properties of drilling mud. Paper SPE 163023 Presented at Nigerian Annual International Conference and Exhibition, Abuja, Nigeria, 6-8 August, 2012.

Khodja, M., Khodja-Saber, M., Canselier, J.P., et al. Drilling fluid technology: Performances and environmental considerations. Intechopen Access Publisher, 2010.

Makinde, F.A., Adejumo, A.D., Ako, C.T., et al. Modelling the effects of temperature and ageing time on the rheological properties of drilling fluids. Pet. Coal 2011, 53(3): 167182.

Mitchell, R.F., Lake, L.W. Petroleum Engineering Handbook: Drilling Engineering. USA, SPE, 2006.

Mohamadian, N., Ghorbani, H., Wood, D. Rheological and filtration characteristics of drilling fluids enhanced by nanoparticles with selected additives: An experimental study. Adv. Geo-Energy Res. 2018, 2(3): 228-236.

Nash, V.E. Role of exchangeable cations in viscosity of clay suspensions. Clays Clay Miner. 2013, 7(1): 328-342.

Nasser, J., Jesil, A., Mohiuddin, T., et al. Experimental investigation of drilling fluid performance as nanoparticles. World J. Nano Sci. Eng. 2013, 3: 57-61.

Ogbeide, P.O., Igbinere, S.A. The effect of additives on rheological properties of drilling fluid in highly deviated wells. Futo J. Ser. 2016, 2(2): 68-82.

Shah, S.N., Shanker, N.H., Ogugbue, C.C. Future challenges of drilling fluids and their rheological measurements. Paper AADE-10-DF-HO-41 Presented at 2010 AADE Fluids Conference and Exhibition, Hilton Houston North, Houston, Texas, 6-7 April, 2010.

Yunita, P., Irawan, S., Kania, D. Optimization of water-based drilling fluid using non-ionic and anionic surfactant additives. Procedia Eng. 2016, 148: 1184-1190. 